68

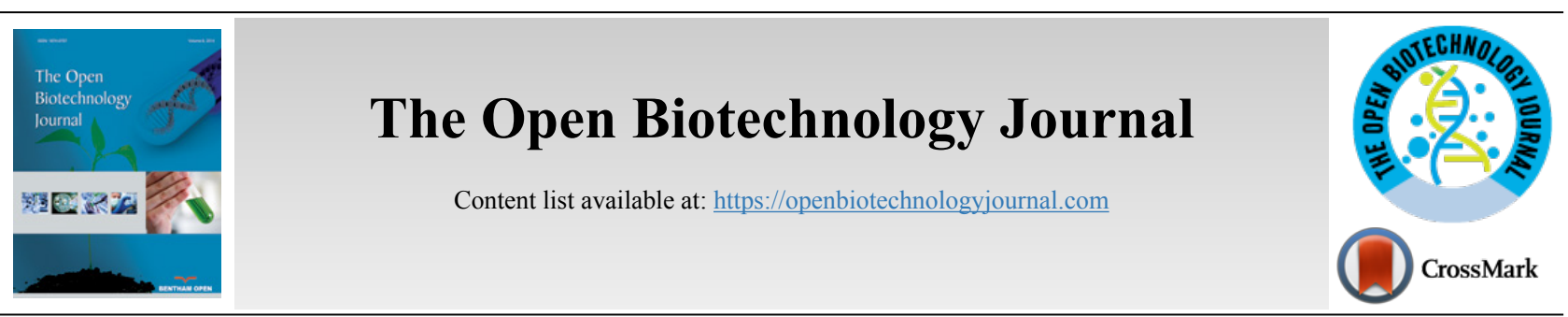

REVIEW ARTICLE

\title{
Antinutrients in Plant-based Foods: A Review
}

\author{
Aneta Popova ${ }^{1}$ and Dasha Mihaylova ${ }^{2, *}$ \\ ${ }^{1}$ Department of Catering and Tourism, University of Food Technologies, 26 Maritza Blvd., 4002, Plovdiv, Bulgaria \\ ${ }^{2}$ Department of Biotechnology, University of Food Technologies, 26 Maritza Blvd., 4002, Plovdiv, Bulgaria
}

\begin{abstract}
Modern society has easy access to a vast informational database. The pursuit of sustainable green and healthy lifestyle leads to a series of food choices. Therefore, it is of importance to provide reliable, comprehensive and up-to-date information about food content including both nutritional and antinutritional elements.

Nutrients are associated with positive effects on human health. Antinutrients, on the other hand, are far less popular for the contemporary man. They are highly bioactive, capable of deleterious effects as well as some beneficial health effects in man, and vastly available in plant-based foods. These compounds are of natural or synthetic origin, interfere with the absorption of nutrients, and can be responsible for some mischievous effects related to the nutrient absorption. Some of the common symptoms exhibited by a large amount of antinutrients in the body can be nausea, bloating, headaches, rashes, nutritional deficiencies, etc. Phytates, oxalates, and lectins are few of the well-known antinutrients.

Science has acknowledged several ways in order to alter the negative influence antinutrients exhibiting on human health. Mechanical, thermal and biochemical approaches act synergistically to provide food with lower antinutritional levels.

The purpose of this review was to synthesize the availability of antinutrients, clear their effect on the human body, and commemorate possible paths to disable them. This review provides links to the available literature as well as enables a systematic view of the recently published research on the topic of plant-based antinutrients.
\end{abstract}

Keywords: Antinutritional factors, Plant-based foods, Beneficial effect, Antinutrients, Food content, Biochemical approaches .

\begin{tabular}{|c|c|c|c|}
\hline Article History & Received: March 08, 2019 & Revised: May 22, 2019 & Accepted: June 06, 2019 \\
\hline
\end{tabular}

\section{INTRODUCTION}

Food is an essential part of people's lives. Despite the world produces enough food for everyone, over 800 million people still go to bed hungry [1]. Furthermore, malnutrition and hunger-related diseases cause over $60 \%$ of deaths [2]. Eliminating hunger and malnutrition is one of the most fundamental challenges facing humanity [3]. Moreover, food sufficiency is not the last aspect of importance; food nutritional quality is of critical demand as well as the effects of the accepted food portion, in particular. From this point of view, the topic of the present review antinutrients raises essential questions about human health and contributes to the understanding of what people actually eat and what the possible resulting effects can be.

Antinutritional factors are primarily associated with compounds or substances of natural or synthetic origin, which interfere with the absorption of nutrients, and act to reduce nutrient intake, digestion, and utilization and may produce

\footnotetext{
* Address correspondence to this author at the Department of Biotechnology, University of Food Technologies, 26 Maritza Blvd., 4002, Plovdiv, Bulgaria; Tel: +359898 742 397; E-mail: dashamihaylova@yahoo.com
}

other adverse effects. Antinutrients are frequently related to plant-based, raw or vegan diets and are naturally synthesized in plants [4]. Some of the common symptoms exhibited by a large number of antinutrients in the body can be nausea, bloating, headaches, rashes, nutritional deficiencies, etc. [5]. On the other hand, such chemical compounds can be evidently advantageous to humankind when consumed wisely. In fact, plants, for their own defense, primarily use antinutrients.

Although people's sensitivity to antinutrients widely differs adequate food processing is initially recommended to reduce antinutritional factors [6]. A person cannot eliminate antinutrients once they have been introduced to the body. Eliminating and reintroducing specific foods that contain antinutrients can clear the correlation between symptoms and effects on human health. In this regard, the biochemical effects of the anti-nutritional factors are an object of research interest [7 - 10] Most of the secondary metabolites, acting as antinutrients, elicit very harmful biological responses, while some of them are widely applied in nutrition and as pharmacologically-active agents [11, 12].

Antinutrients are found in their highest concentrations in 
grains, beans, legumes and nuts, but can also be found in leaves, roots and fruits of certain varieties of plants. The major antinutrients found in plant-based foods are phytates, tannins, lectins, oxalates, etc. Antinutrients in vegetables, whole grains, legumes and nuts are a concern only when a person's diet is composed exclusively of uncooked plant foods. Oxalate, for instance, prevents calcium from being absorbed in the body by binding with it [13]. Raw spinach, kale, broccoli and soybeans usually contain oxalates [14]. When consuming excessive tannins, which are associated with tea, wine, some fruit, and chocolate, enzymes responsible for protein absorption may be inactivated. Phytates are present in grains, nuts and seeds, while peppers, eggplants, and tomatoes contain lectins. Phytates consumption may lead a lower mineral absorption and lectins are able to cause various reactions to the body [15]. Saponins, on the other hand, have been linked to red blood cells damaging, enzyme inhibition and thyroid function intervention [16].

There are several approaches to oppose antinutritional factors. Modern biotechnology`s techniques could reduce the level of certain allergens and antinutrients in food. Genome editing biotechnology can create mutations and substitutions in plant and other eukaryotic cells based on nuclease-based forms of engineering such as the TALENS (Transcription ActivatorLike Effector Nucleases) or the CRISPR (Clustered Regularly Interspaced Short Palindromic Repeats)/CRISPR-Associated Systems (CAS) [17, 18]. Providing an enhanced level of prebiotic in the body can positively influence the effects of antinutrients [19]. A classic approach to remove antinutrients is to treat the product thermally, use methods such as extrusion, autoclaving, hydrotechniques, enzymatic and harvest treatments, etc. [20].

The nutritional value of foods strongly depends on their nutritional and antinutritional composition. This review was designed to synthesize the availability of antinutrients, clear their effect on the human body, and commemorate possible paths to disable them.

\section{ANTINUTRIENTS IN PLANT-BASED FOODS}

\subsection{Lectins}

Lectins, particularly abundant in plants, are proteins or glycoproteins of non-immune origin. They have the ability to bind, without modifying, to either carbohydrates or glycoconjugates (glycoproteins, glycolipids, polysaccharides). They can successfully recognize animal cell carbohydrates, which corresponds to the Latin derivation of the word legere meaning to select [21]. Lectins have a variety of roles. They can bypass human defense system and travel all over the body causing diseases (i.e. Crohn's disease, Coeliac-Sprue, colitis, etc.) by breaking down the surface of the small intestine [22]. When large quantities of lectins are introduced in the body, the gut wall develops holes, and intestinal permeability, causing the leaky gut syndrome. Lectins can make cells act as if they have been stimulated by insulin or cause the insulin release by the pancreas. Lectins can also cause autoimmune diseases by presenting wrong immune system codes and stimulating the growth of some white blood cells [23, 24]. This may possibly lead to cancer but lectins have not yet been recognized as cancer causing.

Not all variety of lectins are toxic or responsible for intestinal damage. Lectins can be found in plant species such as wheat, beans, quinoa, peas, etc. [25]. As grains are a common part of the birds' diet, it has been found that birds themselves are resistant to grains lectins [26]. Acne, inflammation, migraines or joint pains can be caused by the consumption of lectins [27]. Lectins are usually found in the hull so choosing white rice can lower the lectin intake. Heating plant sources in the process of cooking can significantly lower the amount of lectins in them. White potatoes, for instance, have a higher lectin content compared to sweet potatoes [28]. Almonds are also a richer lectin source than peanuts [29].

\subsection{Trypsin Inhibitors}

Trypsin inhibitors occur in a wide range of foods like chickpeas, soybeans, red kidney beans, adzuki beans, mung beans and other representatives of the Leguminoseae, Solanaceae, and Gramineae families [30]. Ten percent of the world's dietary protein is derived from grain legumes [31]. Trypsin inhibitors redound to the loss of trypsin and chymotrypsin in the gut, thus preventing protein digestion. Excess trypsin synthesis and burden on sulfur-containing amino acids in requirement of the body are due to the release of cholecystokinin triggered by trypsin inhibitors [32].

\subsection{Alpha-amylase Inhibitors}

Inhibition of $\alpha$-amylase is considered a strategy for the treatment of disorders in carbohydrate uptake, by reducing insulin levels, as well as, dental caries and periodontal diseases [33]. Amylase inhibitors are substances that bind to alpha amylases making them inactive [34]. Two roles of $\alpha$-amylase inhibitors have been identified. The primary function of inhibitors is protecting the seed against microorganisms and pests, and the other function is the inhibition of the endogenous $\alpha$-amylase [35]. However, the instability of this inhibitor under the conditions of the gastrointestinal tract and being a very heat-liable constituent results in its failure to be used as starch blocker [36]. It is used to control human diabetes type two [37] and finds several applications in the food industry $[38,39]$.

\subsection{Protease Inhibitors}

Proteases are key cell-process-regulation enzymes that are found in all cells and tissues. Protease inhibitors are commonly present in raw cereals and legumes, especially soybean. Protease inhibitors bind to their target proteins reversibly or irreversibly. Growth inhibition, pancreatic hypertrophy [40], and poor food utilization [41] are associated with protease inhibitors' antinutrient activity. Exopeptidases remove amino acids from the $\mathrm{C}$ - or N-terminus, whereas endopeptidases are capable of cleaving peptides within the molecule [42]. Grain eating birds have evolved digestive enzymes that are resistant to grain protease inhibitors [26]. In human volunteers and in animal experiments, high levels of protease inhibitors lead to an increased secretion of digestive enzymes by the pancreas [43]. 
Table 1. Antinutrients in different foods $[29,68-80]$.

\begin{tabular}{|c|c|c|}
\hline Source & Type & Amount \\
\hline $\begin{array}{c}\text { Legumes (soya, lentils, chick peas, peanuts, } \\
\text { beans) }\end{array}$ & $\begin{array}{c}\text { Phytic acid } \\
\text { Saponins } \\
\text { Cyanide } \\
\text { Tannins } \\
\text { Trypsin inhibitor } \\
\text { Oxalates }\end{array}$ & $\begin{array}{c}386-714 \mathrm{mg} / 100 \mathrm{~g} \\
106-170 \mathrm{mg} / 100 \mathrm{~g} \\
2-200 \mathrm{mg} / 100 \mathrm{~g} \\
1.8-18 \mathrm{mg} / \mathrm{g} \\
6.7 \mathrm{mg} / 100 \mathrm{~g} \\
8 \mathrm{mg} / \mathrm{kg}\end{array}$ \\
\hline $\begin{array}{c}\text { Grains (wheat, barley, rye, oat, millet, corn, } \\
\text { spelt, kamut, sorgho) }\end{array}$ & $\begin{array}{l}\text { Phytic acid } \\
\text { Oxalates }\end{array}$ & $\begin{array}{c}50-74 \mathrm{mg} / \mathrm{g} \\
35-270 \mathrm{mg} / 100 \mathrm{~g}\end{array}$ \\
\hline $\begin{array}{l}\text { Pseudo-grains: quinoa, amaranth, wheat, } \\
\text { buckwheat, teff }\end{array}$ & $\begin{array}{l}\text { Phytic acid } \\
\text { Lectins } \\
\text { Saponins } \\
\text { Goitrogens }\end{array}$ & $\begin{array}{l}0.5-7.3 \mathrm{~g} / 100 \mathrm{~g} \\
0.04-2.14 \mathrm{ppm}\end{array}$ \\
\hline $\begin{array}{c}\text { Nuts: almonds, hazelnut, cashew, pignola, } \\
\text { pistachio, brazil nuts, walnuts, macadamia, } \\
\text { etc. }\end{array}$ & $\begin{array}{l}\text { Phytic acid } \\
\text { Lectins } \\
\text { Oxalates }\end{array}$ & $\begin{array}{c}150-9400 \mathrm{mg} / 100 \mathrm{~g} \\
37-144 \mu \mathrm{g} / \mathrm{g} \\
40-490 \mathrm{mg} / 100 \mathrm{~g}\end{array}$ \\
\hline $\begin{array}{l}\text { Seeds: sesame, flaxseed, poppy seed, } \\
\text { sunflower, pumpkin }\end{array}$ & $\begin{array}{l}\text { Phytic acid } \\
\text { Alpha-amylase inhibitor } \\
\text { Cyanide }\end{array}$ & $\begin{array}{l}1-10.7 \mathrm{~g} / 100 \mathrm{~g} \\
0.251 \mathrm{mg} / \mathrm{mL} \\
140-370 \mathrm{ppm}\end{array}$ \\
\hline $\begin{array}{l}\text { Tubers: carrot, sweet potato, Jerusalem } \\
\text { artichoke, manioc (or tapioca), yam }\end{array}$ & $\begin{array}{l}\text { Oxalates } \\
\text { Tannins } \\
\text { Phytates }\end{array}$ & $\begin{array}{c}0.4-2.3 \mathrm{mg} / 100 \mathrm{~g} \\
4.18-6.72 \mathrm{mg} / 100 \mathrm{~g} \\
0.06-0.08 \mathrm{mg} / 100 \mathrm{~g}\end{array}$ \\
\hline $\begin{array}{c}\text { Nighshades: potato, tomato, eggplant, } \\
\text { pepper }\end{array}$ & $\begin{array}{l}\text { Phytic acid } \\
\text { Tannins } \\
\text { Saponins } \\
\text { Cyanide }\end{array}$ & $\begin{array}{c}0.82-4.48 \mathrm{mg} / 100 \mathrm{~g} \\
0.19 \mathrm{mg} / 100 \mathrm{~g} \\
0.16-0.25 \mathrm{mg} / 100 \mathrm{~g} \\
1.6-10.5 \mathrm{mg} / 100 \mathrm{~g}\end{array}$ \\
\hline
\end{tabular}

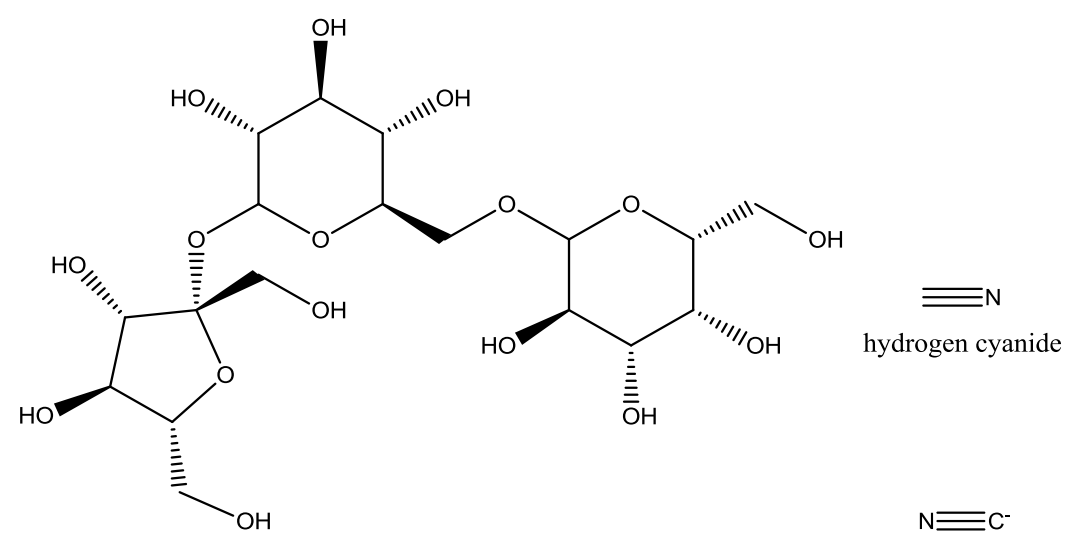<smiles>O=P(O)(O)O[C@H]1[C@H](OP(=O)(O)O)[C@@H](OP(=O)(O)O)[C@H](OP(=O)(O)O)[C@@H](OP(=O)(O)O)[C@H]1OP(=O)(O)O</smiles>

cyanide

Fig. (1). Structure of some antinutrient substances. 


\subsection{Tannins}

Plant tannins are a major group of antioxidant polyphenols found in food and beverages that attracts research interest with its multifunctional properties to human health. Tannins are oligomers of flavan-3-ols and flavan-3, 4-diols that are concentrated in the bran fraction of legumes [44]. Grapes and green tea are rich in this water-soluble polyphenol [45]. Tannins exhibit antinutritional properties by impairing the digestion of various nutrients and preventing the body from absorbing beneficial bioavailable substances [46]. Tannins can also bind and shrink proteins. Tannin-protein complexes may cause digestive enzymes inactivation and protein digestibility reduction caused by protein substrate and ionisable iron interaction [47].

\subsection{Phytates}

Phytates occur in several vegetable products. Seeds, grains, nuts and legumes store phosphorus as phytic acid in their husks in the form of phytin or phytate salt. Their presence may affect bioavailability of minerals, solubility, functionality and digestibility of proteins and carbohydrates [41]. Phytic acid is most concentrated in the bran of grains [48]. In legumes, phytic acid is found in the cotyledon layer and can be removed prior to consumption [49]. The digestive enzyme phytase can unlocked the phosphorus stored as phytic acid. In the absence of phytase, phytic acid can impede the absorption of other minerals like iron, zinc, magnesium and calcium by binding to them [50]. This results in highly insoluble salts that are poorly absorbed by the gastrointestinal tract leading to lower bioavailability of minerals. Phytates also inhibit digestive enzymes like pepsin, trypsin and amylase [51].

\subsection{Goitrogens}

Hypothyroidism is increasing daily worldwide as the thyroid gland is highly sensitive to stress and environmental stimuli [52]. Goitrogens interfere with iodine uptake and thus, affect thyroid function. Vegetables from the genus Brassica i.e. broccoli, cabbage, cauliflower, Brussels sprouts and kale are some of the goitrogen rich foods [53]. The consumption of cruciferous vegetables affects triiodothyronine (T3) and thyroxine (T4) levels by causing hypothyroidism [54]. Concomitant factors can be insufficient water consumption and protein malnutrition [55].

\subsection{Raffinose Oligosaccharides}

Raffinose, stachyose and verbascose, all part of the Raffinose Family Oligosaccharides (RFOs), are synthesized from sucrose. Non-digestible oligosaccarides have a prebiotic effect in the lower intestine by promoting the growth of Bifidobacterium and Lactobacillus that inhibit pathogenic growth [56]. The absence of appropriate enzyme activity to hydrolyse RFOs ( $\alpha$-galactosidase) leads to the inability of humans and to digest RFOs an allow them to pass through the intestinal wall intact $[51,57]$. A correlation between legumes consumption and the likelihood of intestinal discomfort has been drawn leading to symptoms like burping, abdominal pain, and bloating [57]. The presence of RFO in the daily food intake can interfere with the digestion nutrients [58]. RFO can reduce metabolizable energy and protein utilization [59]. Research has shown that RFO removal has improved the digestion of all amino acids increasing the overall nutritional value of the lupin $\operatorname{diet}[60]$.

\subsection{Saponins}

Some saponins (steroid or triterpene glycoside compounds) can be used for food while others are toxic. Saponins with a bitter taste are toxic in high concentrations and can affect nutrient absorption by inhibiting enzymes (metabolic and digestive) as well as by binding with nutrients such as zinc. Saponins are naturally occurring substances with various biological effects. In the presence of cholesterol, saponins exhibit strong hypocholesterolemic effect [61]. They can also lead to hypoglycemia [62] or impair the protein digestion, uptake vitamins and minerals in the gut, as well as lead to the development of a leaky gut [63].

\subsection{Oxalates}

Some organic acids can have antinutritional factors. Oxalic acid can form soluble (potassium and sodium) or insoluble (calcium, magnesium, iron) salts or esters called oxalates that are commonly found in plants i.e. leafy vegetables or synthesized in the body [64]. Insoluble salts cannot be processed out of the urinary tract once processed through the digestive system. Calcium oxalate can have a deleterious effect on human nutrition and health by accumulating kidney stones [65]. Cruciferous vegetables (kale, radishes, cauliflower, broccoli), as well as chard, spinach, parsley, beets, rhubarb, black pepper, chocolate, nuts, berries (blueberries, blackberries) and beans are some of the foods with high amounts of oxalates [66]. Most people can induct normal amounts of oxalate rich foods, while people with certain conditions, such as enteric and primary hyperoxaluria, need to lower their oxalate intake. In sensitive people, even small amounts of oxalates can result in burning in the eyes, ears, mouth, and throat; large amounts may cause abdominal pain, muscle weakness, nausea, and diarrhea [67].

Table $\mathbf{1}$ is revealing some food sources with the typical antinutrients contained in them as well as the amounts variables.

\subsection{Exorphins}

The alcohol-soluble proteins (proalimins) of cereal grains and dairy products called gliadins can be further degraded to a collection of opioid-like polypeptides named exorphins in the gastrointestinal tract [81]. Behavioral traits such as spontaneous behavior, memory, and pain perception can be affected by the bioactivity of food-derived exorphins [82]. Exorphins can also influence gastric emptying and intestinal transit by increasing its time [83]. The digestion of milk produces alphacasein-derived exorphins [84]. Recent research suggests that epigenetic effects of milk-derived opiate peptides may contribute to gastrointestinal dysfunction and inflam-mation in sensitive individuals [85].

Fig. (1) pinpoints some of the widely speard antinutrients in plant-based foods. 


\subsection{Contextual Antinutrients}

Some supplements or foods rich in certain nutrients can create reactions of an antinutrient nature. For instance, calcium-rich foods can impede iron absorption. There is also a mutual antagonism between zinc and copper during the absorption process, taking place in/on the intestinal epithelium [86]. Research literature suggests that phytosterols [87] and phospholipids [88] may reduce cholesterol absorption when added to nonfat foods. Some foods can interfere with medication absorption [89]. The most well publicized fooddrug interaction is that of grapefruit and a variety of drugs. Bergamottin found in grapefruit juice inactivates drugmetabolizing enzymes. This is the reason why food interaction warnings are listed on some medical labels. Studies have found that resveratrol, found in red wine and peanuts, inhibits platelet aggregation, and high intakes could increase the risk of bleeding when consumed with anticoagulant drugs [90]. Canadian researchers have documented that black tea was a more powerful enzyme inhibitor than single-ingredient herbal teas (St. John's Wort, feverfew, cat's claw, etc.) [91]. Another well-known food-drug interaction is that of foods containing tyramine (chocolate, beer, wine, avocados, etc.) and monoamine oxidase inhibitors (type of antidepressant) [92]. The most medically consequential food-drug interaction is that of vitamin K-rich foods (e.g. broccoli, spinach) and Coumadin, an anticoagulant prescribed to thin the blood and prevent clots [93].

\section{ANTINUTRIENTS AND HUMAN HEALTH}

While antinutrients can be problematic, some may also provide health benefits. The consumers should be aware of any possible effect whether beneficial and/or negative. Moreover, concentration-dependent effects must be considered. Data may be manipulated in respect of health related advantages so that chronic diseases management becomes possible [32].

Antinutrients are valuable active ingredients in food and drinks. When used at low levels, phytic acid, lectins and phenolic compounds as well as enzyme inhibitors and saponins have been shown to reduce blood glucose and/or plasma cholesterol and triacylglycerols. Furtermore, saponins are reported to act effectively in maintaining liver function, preventing steoporosis as well as platelet agglutination [94]. Meanwhile, phenolic compounds from plant sources, phytic acid, protease inhibitors, saponins, lignans and phytoestrogens have been demonstrated to reduce cancer risks. Another group of antinutrient compounds, like tannins, were found to possess possible antiviral [95], antibacterial [96] and antiparasitic effects [97].

Some compounds such as phytoestrogens and lignans have also been linked to induction of infertility in humans. Therefore, it is prudent to examine all aspects of food antinutrients, including their potential health benefits and methods of analyses [32].

The above mentioned implies that antinutrients could be valuable tools for managing various diseases. They might not always be harmful even though they lack nutritional value. What is most important is focusing on dosage intake in order to find the balance between beneficial and hazardous effects of plant bioactives and antinutrients, in addition to the chemical structure, time of exposure and interaction with other dietary components. Many factors influence their activity. They can both be considered as antinutritional factors with negative effects or non-nutritive compounds with positive health effects. Consumers' awareness is crucial especially when abnormal health conditions are established.

\section{DISABLING ANTINUTRIENTS}

Removing undesirable food components is essential to their quality improvement. Different techniques i.e. soaking, cooking, fermentation, radiation, germination and chemical treatment can come in as handy instruments for antinutritional disabling $[98,99]$. The combination of several of the abovementioned methods may be more effective in removing antinutrients than using a sole technique.

Soaking: Soaking can be seen as one of the easiest physical processes to remove soluble antinutritional factors. Soaking in distilled water, $1 \% \mathrm{NaHCO}_{3}$ and mixed salt solutions reduced total phenols, ortho-dihydroxyphenols, tannins and phytates by $33,41,35$ and 21 percentages respectively [100]. Soaking decreased the total protein, soluble sugar and tannins, in soybean flour [101]. Soaking and sprouting grains, nuts, seeds, and beans are an excellent way to deactivate enzyme inhibitors [102]. However, lectin is not affected by this method of deactivation.

Fermentation: Fermenting assorted grain flour with $L$. acidophilus at $37^{\circ} \mathrm{C}$ for $24 \mathrm{~h}$ led to the reduction of phytic acid and polyphenol content [103]. Recent research has shown a general noticeable reduction in the entire antinutrient properties of soybean for a day of fermentation [104]. Ojokoh et al. [105] have studied the effect of fermentation on the antinutritional composition of breadfruit and cowpea flours showing a significant reduction of the hydrogen cyanide, oxalate and phytate content. Fermentation is reported to increase the protein content in chickpea by $13 \%$ and decrease the content of phytic acid by $45 \%$ [106]. Adeyemo et al. [107] assessed the effects of fermentation of sorghum at 0,72 and 120 hours on trypsin inhibitor, protease inhibitor, phytate and tannin. A significant reduction of trypsin inhibitor $(69 \%)$; protease inhibitor (30\%); phytate $(60 \%)$ and tannin $(72 \%)$ was observed at $120 \mathrm{~h}$ with $L$. plantarum used as starter culture. On the other hand, $L$. brevis as starter appeared to be effective at $120 \mathrm{~h}$ with $58 \%$ reduction of trypsin inhibitor; $40 \%$ of protease inhibitor; $70 \%$ of phytate and $56 \%$ of tannin.

Sprouting (Germination): Germination is one of the most effective processes for the reduction of anti-nutritive compounds i.e. phytate levels [108]. The trypsin inhibitor activity, amylase inhibitor activity and phytate content of soy-bean variety MACS-13 decreased with sprouting [109]. Kanensi et al. [110] report a lower antinutrient level of germi-nated amaranth seeds. The levels of tannins and phytate were insignificant. To overcome the antinutritional levels, Kajla et al. [111] also adopted the germination process in flax seeds. Other authors reaffirm that germination leads to increased nutritional and decreased anti-nutrients content in plant-based foods [112].

Heating: Cooking whole grains, beans and vegetables can 
reduce certain antinutrients such as phytic acid, tannins, and oxalic acid. Protease inhibitors are easily denatured by heat treatment due to their protein nature [113]. Research has shown that antinutrient levels are reduced with controlled heating at a temperature less than boiling for at least 15 minutes [114]. Autoclaving can also drastically decrease the content of tannins, phytic acid, hydrogen cyanide, trypsin inhibitors and oligosaccharides [6]. Cooking sweet potato leaves with lemon reduced polyphenols with $56 \%$ and lowered the oxalate levels [115]. Boiling bambara groundnut seeds for a period of $60 \mathrm{~min}$ significantly lowers the raffinose content and improves protein digestibility of the seeds [116].

Gamma radiation: Gamma radiation appeared to be a good procedure to decrease the level of trypsin inhibitor, phytic acid and oligosaccharides of broad bean between 5 and $10 \%$ [117]. However, Hassan et al. [118] documented that a $2 \mathrm{kGy}$ dose had no significant change in the tannin content of two maize cultivars. Similar observations were reported by ElNiely [119] and Fombang et al. [120]. Low doses of gamma irradiation ( 0.5 and $1.0 \mathrm{kGy})$ Faba bean seeds significantly reduced antinutritional factors such as tannin and phytic acid [121]. Gamma radiation can be applied as a safe postharvest method to minimize antinutrients of millet grains [122].

Genomic technology: Genomic resources can be used as pathways to RNA interference and removing of antinutrient factors, but this technology has yet to be tried out in vivo [123]. Shukla et al. [124] designed zinc-finger nucleases construct to mutate the IPK1 gene in maze, one of the phytic acid biosynthesis genes because corn contains high levels of phosphorus stored in the form of phytic acid. Genome editing technology can increase crop quality but there is an ongoing argument about genetically modified organisms' safety [125].

\section{CONCLUSION}

Antinutritional factors are widespread food compounds that are especially challenging for those choosing a predominantly plant-based diet i.e. vegan, vegetarians, etc. Antinutrients can exhibit beneficial health effects if present in small amounts or cause nutrient deficiencies. Uninformed consumers may deal with some misleading information when the latter is not sufficiently available. Antinutrients may induce their undesirable effects when consumed above their upper limit. Harmful effects can also be due to antinutritional breakdown products. Thus, the presence of lectins, tannins, alkaloids, and saponins, goitrogens, inhibitors, etc. in foods may induce various reactions when the consumer is presented with little knowledge related to the environmental influence on the detoxification capacity of the human organism. Classic approaches and modern agricultural biotechnological programs can serve as antinutritional removal tools. However, health risk factors can be avoided when a daily sustainable diet lying on a sound scientific basis is introduced.

\section{CONSENT FOR PUBLICATION}

Not applicable.

\section{FUNDING}

None.

\section{CONFLICT OF INTEREST}

The authors declare no conflict of interest, financial or otherwise.

\section{ACKNOWLEDGEMENTS}

Declared none.

\section{REFERENCES}

[1] FAO. IFAD and WFP 2015.

[2] UNICEF. 2007. The State of the World's Children. Women and Children The Double Dividend of Gender Equality

[3] Lomborg B, Ed. Global Crises, Global Solutions. Cambridge: Cambridge University Press 2004.

[http://dx.doi.org/10.1017/CBO9780511492624]

[4] Gemede HF, Ratta N. Antinutritional factors in plant foods: potential health benefits and adverse effects. Int J Nutr Food Sci 2014; 3(4): 284-9.

[http://dx.doi.org/10.11648/j.ijnfs.20140304.18]

[5] Essack H, Odhav B, Mellem JJ. Screening of traditional South African leafy vegetables for selected anti-nutrient factors before and after processing. Food Sci Technol 2017; 3: 462-1.

[http://dx.doi.org/10.1590/1678-457x.20416]

[6] Soetan $\mathrm{K}$, Oyewole O. The need for adequate processing to reduce the anti-nutritional factors in plants used as human foods and animal feeds: A review. Afr J Food Sci 2009; 3(9): 223-32. [http://dx.doi.org/10.3109/08039489709090718].

[7] Cheeke PR, Shull LR. Natural toxicants in feeds and livestock. West Port, Connecticut: AVI Publishing Inc. 1985.

[8] Aletor VA. Allelochemicals in plant foods and feedingstuffs: 1 Nutritional, biochemical and physiopathological aspects in animal production. Vet Hum Toxicol 1993; 35(1): 57-67. [PMID: 8434459]

[9] Osagie AU. 1998.Antinutritional factors.

[10] Fu PP, Xia Q, Lin G, Chou MW. Genotoxic pyrrolizidine alkaloidsmechanisms leading to DNA adduct formation and tumorigenicity. Int J Mol Sci 2002; 3: 948-64.

[http://dx.doi.org/10.3390/i3090948]

[11] Oakenfull D, Sidhu GS. Saponins: In Toxicants of plant origin, Vol. II, Glycosides. In: Florida: CRC. Press Inc 1989; p. 97.

[12] Soetan KO. Pharmacological and other beneficial effects of antinutriional factors in plants. -A review. Afr J Biotechnol 2008; 7(25): 4713-21. [https://doi.org/10.5897/AJB08.024].

[13] Jiru K, Urga K. Ethiop. Forms and contents of oxalate and calcium in some vegetables in Ethiopia. J Health Dev 1995; 9(1): 13-8.

[14] Savage G, Klunklin W. Oxalates are found in many different european and asian foods - effects of cooking and processing. J Food Res 2018; $7(3)$

[http://dx.doi.org/10.5539/jfr.v7n3p76]

[15] Gupta RK, Gangoliya SS, Singh NK. Reduction of phytic acid and enhancement of bioavailable micronutrients in food grains. J Food Sci Technol 2015; 52(2): 676-84.

[http://dx.doi.org/10.1007/s13197-013-0978-y] [PMID: 25694676]

[16] Fan Y, Guo DY, Song Q, Li T. Effect of total saponin of aralia taibaiensis on proliferation of leukemia cells. Zhong Yao Cai 2013; 36(4): 604-7.

[PMID: 24134011]

[17] Gaj T, Gersbach CA, Barbas CF III, Barbas CF. ZFN, TALEN, and CRISPR/Cas-based methods for genome engineering. Trends Biotechnol 2013; 31(7): 397-405.

[http://dx.doi.org/10.1016/j.tibtech.2013.04.004] [PMID: 23664777]

[18] Jankele R, Svoboda P. TAL effectors: tools for DNA targeting. Brief Funct Genomics 2014; 13(5): 409-19.

[http://dx.doi.org/10.1093/bfgp/elu013] [PMID: 24907364]

[19] Gibson RS, Perlas L, Hotz C. Improving the bioavailability of nutrients in plant foods at the household level. Proc Nutr Soc 2006; 65(2): $160-8$

[http://dx.doi.org/10.1079/PNS2006489] [PMID: 16672077]

[20] Muzquiz M, Hill GD, Cuadrado C, Pedrosa MM, Burbano C. Recent advances of research in antinutritional factors in legume seeds and oilseeds. Proceedings of the fourth international workshop on antinutritional factors in legume seeds and oilseeds. Toledo, Spain. 2004.

[http://dx.doi.org/10.3920/978-90-8686-524-6] 
[21] Boyd WC, Shapleigh E. Specific precipitating activity of plant agglutinins (lectins). Science 1954; 119(3091): 419.

[http://dx.doi.org/10.1126/science.119.3091.419] [PMID: 17842730]

[22] Yasuoka T, Sasaki M, Fukunaga T, et al. The effects of lectins on indomethacin-induced small intestinal ulceration. Int J Exp Pathol 2003; 84(5): 231-7.

[http://dx.doi.org/10.1111/j.1365-2613.2003.00360.x] [PMID: 14690482]

[23] Karpova IS. Specific interactions between lectins and red blood cells of Chornobyl cleanup workers as indicator of some late radiation effects. Exp Oncol 2016; 38(4): 261-6.

[http://dx.doi.org/10.31768/2312-8852.2016.38(4):261-266] [PMID: 28230832]

[24] Fahmi N, Sharma N, Pandey A, et al. Interactions of lectins in the red blood cells of oral squamous cell carcinoma patients: A comparative study. Int J Curr Adv Res 2017; 6(7): 4753-7.

[25] Peumans WJ, Van Damme EJ, Barre A, Rougé P. Classification of plant lectins in families of structurally and evolutionary related proteins. Adv Exp Med Biol 2001; 491: 27-54. [http://dx.doi.org/10.1007/978-1-4615-1267-7 3] [PMID: 14533788]

[26] Losvik A, Beste L, Mehrabi S, Jonsson L. The protease inhibitor CI2c gene induced by bird cherry-oat aphid in barley inhibits green peach aphid fecundity in transgenic arabidopsis. Int J Mol Sci 2017; 18(6): 1317.

[http://dx.doi.org/10.3390/ijms18061317] [PMID: 28632160]

[27] Singh H, Sarathi SP. Insight of lectins-a review. Int J Sci Eng Res 2012; 3(4): 2-9.

[28] Zubcevic N, Suljević D, Muhamed F, Rukavina D. Effects of plant lectins on human erythrocyte agglutination. Serb J Exp Clin Res 2016; 17(3): 207-13.

[http://dx.doi.org/10.1515/sjecr-2016-0031]

[29] Kumari S. 2018.The Effect of Soaking Almonds and Hazelnuts on Phytate and Mineral Concentrations http://hdl.handle.net/10523/7938

[30] Tibe O, Amarteifio JO, Njogu RMJ. Trypsin inhibitor activity and condensed tannin content in bambara groundnut (Vigna subterranea (L.) Verdc) grown in Southern Africa. Appl Sci Environ Manage 2007; 11(2): 159-4.

[31] Klupšaitė D, Juodeikienė G. Legume: composition, protein extraction and functional properties. A review Chem Technol 2011; 66: 5-12.

[32] Shahidi F. ACS Symposium Series. 1-9.

[33] Sales PM, Souza PM, Simeoni LA, Silveira D. $\alpha$-Amylase inhibitors: A review of raw material and isolated compounds from plant source. $J$ Pharm Pharm Sci 2012; 15(1): 141-83.

[http://dx.doi.org/10.18433/J35S3K] [PMID: 22365095]

[34] Wisessing A, Choowongkomon K. Amylase inhibitors of plants: structures, functions and applications. Funct Plant Sci Biotechnol 2012; 6: 31-41.

[35] Henry RJ, McKinnon GE, Haak IC, Brennan PS. Use of alpha-amylase inhibitors to control sprouting. St Paul: Preharvest Sprouting in Cereals American Association of Cereal Chemists 1992; pp. 232-5.

[36] Tysoe C, Williams LK, Keyzers R, et al. Potent human $\alpha$-amylase inhibition by the $\beta$-defensin-like protein helianthamide. ACS Cent Sci 2016; 2(3): 154-61.

[http://dx.doi.org/10.1021/acscentsci.5b00399] [PMID: 27066537]

[37] Barrett ML, Udani JK. A proprietary $\alpha$-amylase inhibitor from white bean (Phaseolus vulgaris): A review of clinical studies on weight loss and glycemic control. Nutr J 2011; 1: 10-24.

[38] Iimure T, Takoi K, Kaneko T, et al. Novel prediction method of beer foam stability using protein $Z$, barley dimeric $\alpha$-amylase inhibitor- 1 (BDAI-1) and yeast thioredoxin. J Agric Food Chem 2008; 56(18): 8664-71.

[http://dx.doi.org/10.1021/jf801184k] [PMID: 18710245]

[39] Okada Y, Iimure T, Takoi K, et al. The influence of barley malt protein modification on beer foam stability and their relationship to the barley dimeric $\alpha$-amylase inhibitor-I (BDAI-I) as a possible foampromoting protein. J Agric Food Chem 2008; 56(4): 1458-64. [http://dx.doi.org/10.1021/jf0724926] [PMID: 18237135]

[40] Adeyemo SM, Onilude AA. Enzymatic reduction of anti-nutritional factors in fermenting soybeans by lactobacillus plantarum isolates from fermenting cereals. Niger Food J 2015; 31(2): 84-0. [http://dx.doi.org/10.1016/S0189-7241(15)30080-1]

[41] Salunkhe DK, Chavan JK, Kaden SS. Dietary tannins: Consequences and remedies. Boca Roton, FL: CRC Press 1990; pp. 67-75.

[42] Sakamoto Y, Suzuki Y, Iizuka I, et al. S46 peptidases are the first exopeptidases to be members of clan PA. Sci Rep 2014; 4: 4977. [http://dx.doi.org/10.1038/srep04977] [PMID: 24827749]

[43] Logsdon CD, Ji B. The role of protein synthesis and digestive enzymes in acinar cell injury. Nat Rev Gastroenterol Hepatol 2013; 10(6): 362-70.

[http://dx.doi.org/10.1038/nrgastro.2013.36] [PMID: 23507798]

[44] Ngozi O-OP. Evaluation of tannin, phytate and mineral composition of different indigenous dishes based on pumpkin (Cucurbita pepo). Int $\mathrm{J}$ Nutr Food Sci 2014; 3(6): 493-6.

[http://dx.doi.org/10.11648/j.ijnfs.20140306.11]

[45] Chu X, Guo Y, Xu B, et al. Effects of tannic acid, green tea and red wine on hERG Channels Expressed in HEK293 Cells. PLoS One 2015; 10(12)e0143797

[http://dx.doi.org/10.1371/journal.pone.0143797] [PMID: 26625122]

[46] Hendek Ertop M, Bektaş M. Enhancement of bioavailable micronutrients and reduction of antinutrients in foods with some processes. Food Heal 2018; 4(3): 159-5.

[http://dx.doi.org/10.3153/FH18016]

[47] Salunkhe DK, Chavan JK, Kadam SS. Dietary tannins: Consequences and remedies. Boca Raton, Florida: CRC Press 1990; pp. 150-73.

[48] Wcislo G, Szarlej-Wcislo K. Colorectal cancer prevention by wheat consumption: A three-valued logic - true, false, or otherwise? In: Wheat and Rice in Disease Prevention and Health. In: 2014; pp. 91-111.

[49] Nissar J, Ahad T, Naik HR, et al. A review phytic acid: As antinutrient or nutraceutical. J Pharmacogn Phytochem 2017; 6(6): 1554-60.

[50] Masum Akond ASMG, Crawford H, Berthold J, Talukder ZI, Hossain K. Minerals ( $\mathrm{Zn}, \mathrm{Fe}, \mathrm{Ca}$ and $\mathrm{Mg}$ ) and antinutrient (Phytic acid) constituents in common bean. Am J Food Technol 2011; 6(3): 235-43. [http://dx.doi.org/10.3923/ajft.2011.235.243] [PMID: 29861700]

[51] Kumar V, Sinha AK, Makkar HPS, et al. Dietary roles of phytate and phytase in human nutrition: A review. Food Chem 2010; 945-59. [http://dx.doi.org/10.1016/j.foodchem.2009.11.052]

[52] Vijayalakshmi A, Kiran Kumar Y. Evaluation of goitrogenic and antithyroidal effect of the fern Adiantum capillus-veneris. Brazilian J Pharmacogn 2013; 23: 802-0.

[http://dx.doi.org/10.1590/S0102-695X2013000500013]

[53] Latté KP, Appel KE, Lampen A. Health benefits and possible risks of broccoli - an overview. Food Chem Toxicol 2011; 49(12): 3287-309. [http://dx.doi.org/10.1016/j.fct.2011.08.019] [PMID: 21906651]

[54] Abdul-Aziz A. efficacy of the cruciferous vegetable on the thyroid gland and the gonads in rabbits. Adv Anim Vet Sci 2015; 3(3): 183-. [http://dx.doi.org/10.14737/journal.aavs/2015/3.3.183.191]

[55] Gaitan E. Goitrogens in food and water. Annu Rev Nutr 1990; 10: 21-39.

[http://dx.doi.org/10.1146/annurev.nu.10.070190.000321] [PMID: 1696490]

[56] Berrios JDJ, Morales P, Cámara M, et al. Carbohydrate composition of raw and extruded pulse flours. Food Res Int 2010; 43: 531-6.

[http://dx.doi.org/10.1016/j.foodres.2009.09.035]

[57] Reddy NR, Pierson MD, Sathe SK, et al. Chemical, nutritional and physiological aspects of dry bean carbohydrates-A review. Food Chem 1984; 13: 25-68.

[http://dx.doi.org/10.1016/0308-8146(84)90026-8]

[58] Martínez-Villaluenga C, Frias J, Vidal-Valverde C. Alphagalactosides: Antinutritional factors or functional ingredients? Crit Rev Food Sci Nutr 2008; 48(4): 301-16.

[http://dx.doi.org/10.1080/10408390701326243] [PMID: 18409113]

[59] Leske KL, Zhang B, Coon CN. The use of low alpha-galactoside protein products as a protein source in chicken diets. Anim Feed Sci Technol 1995; 54: 275-86.

[http://dx.doi.org/10.1016/0377-8401(95)00773-G]

[60] Glencross BD, Boujard T, Kaushik SJ. Influence of oligosaccharides on the digestibility of lupin meals when fed to rainbow trout, Oncorhynchus mykiss. Aquaculture 2003; 219: 703-13. [http://dx.doi.org/10.1016/S0044-8486(02)00664-6]

[61] Ikewuchi CC. Hypocholesterolemic effect of an aqueous extract of the leaves of Sansevieria senegambica Baker on plasma lipid profile and atherogenic indices of rats fed egg yolk supplemented diet. EXCLI J 2012; 11: 346-56.

[PMID: 27418909]

[62] Barky A, Hussein S, Alm-Eldeen Y, et al. Saponins and their potential role in diabetes mellitus. Diabetes Manag (Lond) 2017; 7(1): 148-58.

[63] Johnson IT, Gee JM, Price K, Curl C, Fenwick GR. Influence of saponins on gut permeability and active nutrient transport in vitro. $\mathrm{J}$ Nutr 1986; 116(11): 2270-7.

[http://dx.doi.org/10.1093/jn/116.11.2270] [PMID: 3794833]

[64] Akwaowo EU, Ndon BA, Etuk EU. Minerals and antinutrients in fluted pumpkin (Telfairia occidentalis Hook f.). Food Chem 2000; 70(2): 235-40. 
[http://dx.doi.org/10.1016/S0308-8146(99)00207-1]

[65] Olawoye BT, Gbadamosi SO. Effect of different treatments on in vitro protein digestibility, antinutrients, antioxidant properties and mineral composition of Amaranthus viridis seed. Cogent Food Agric 2017; 3: 1.

[http://dx.doi.org/10.1080/23311932.2017.1296402]

[66] Mamboleo T. Nutrients and antinutritional factors at different maturity stages of selected indigenous African green leafy vegetables. 2015

[67] Natesh NH. SK A, L A. An overview of nutritional and anti nutritional factors in green leafy vegetables. Hortic Int Journal 2018; 1(2): 58-65.

[68] Khokhar S, Chauhan BM. Anti-nutritional factors in moth beans (Vigna aconitifolia): Varietal difference and effects of methods of domestic processing and cooking. J Food Sci 1986; 51(3): 591-4. [http://dx.doi.org/10.1111/j.1365-2621.1986.tb13887.x]

[69] Ndidi US, Ndidi CU, Olagunju A, Muhammad A, Billy FG, Okpe O. Proximate, antinutrients and mineral composition of raw and processed (boiled and roasted) sphenostylis stenocarpa seeds from Southern Kaduna, Northwest Nigeria. ISRN Nutr 2014; 2014280837 [http://dx.doi.org/10.1155/2014/280837] [PMID: 24967265]

[70] Margier M, Georgé S, Hafnaoui N, et al. Nutritional composition and bioactive content of legumes: Characterization of pulses frequently consumed in France and effect of the cooking method. Nutrients 2018; 10(11)E1668

[http://dx.doi.org/10.3390/nu10111668] [PMID: 30400385]

[71] Sinha K, Khare V. Review on: Antinutritional factors in vegetable crops. Pharma Innov J 2017; 12: 353-8.

[72] Chai W, Liebman M. Oxalate content of legumes, nuts, and grainbased flours. J Food Compos Anal 2005; 18: 723-9.

[http://dx.doi.org/10.1016/j.jfca.2004.07.001]

[73] Harland BF, Smikle-Williams S, Oberleas D. High performance liquid chromatography analysis of phytate (IP6) in selected foods. J Food Compos Anal 2004; 17: 227-3.

[http://dx.doi.org/10.1016/j.jfca.2003.08.005]

[74] Ahmed E. Peanut and soybean lectin determination. Peanut Sci 1986; 13: 7-10.

[http://dx.doi.org/10.3146/i0095-3679-13-1-2]

[75] Kasim AB, Edwards HMJ. The analysis of inositolphosphate forms in feed ingredients. Sci Food Agric 1998; 76: 1-9.

[http://dx.doi.org/10.1002/(SICI)1097-0010(199801)76:1<1::AID-JSF A922>3.0.CO;2-9]

[76] Shah SB, Sartaj L, Ali F, et al. Plant extracts are the potential inhibitors of $\alpha$-amylase: A review. MOJ Bioequiv Availab 2018; 5(5): 270-3.

[77] Rezaul Haque M, Howard Bradbury J. Total cyanide determination of plants and foods using the picrate and acid hydrolysis methods. Food Chem 2002; 77: 107-14.

[http://dx.doi.org/10.1016/S0308-8146(01)00313-2]

[78] Popoola D, Adusami D. Oxalate content of some Nigerian tubers using titrimetric and UV- spectrophotometric methods. Acad J Agric Res 2014; 2(2): 54-7.

[79] Akalu ZK, Geleta SH. Antinutritional levels of tubers of Colocasia esculenta, L. Schott (Taro) and Dioscorea alata (Yam) cultivated in Ethiopia. J Nutr Food Sci 2017; 7: 585. [http://dx.doi.org/10.4172/2155-9600.1000585]

[80] Akubugwo IE, Obasi AN, Ginika SC. Nutritional potential of the leaves and seeds of black nightshade - Solanum nigrum L. Var virginicum from Afikpo-Nigeria. Pak J Nutr 2007; 6(4): 323-6.

[http://dx.doi.org/10.3923/pjn.2007.323.326]

[81] Tatham AS, Shewry PR. Allergens to wheat and related cereals. Clin Exp Allergy 2008; 38(11): 1712-26.

[PMID: 18823308]

[82] Lister J, Fletcher PJ, Nobrega JN, Remington G. Behavioral effects of food-derived opioid-like peptides in rodents: Implications for schizophrenia? Pharmacol Biochem Behav 2015; 134: 70-8. [http://dx.doi.org/10.1016/j.pbb.2015.01.020] [PMID: 25661529]

[83] Tovoli F, Masi C, Guidetti E, Negrini G, Paterini P, Bolondi L. Clinical and diagnostic aspects of gluten related disorders. World $\mathrm{J}$ Clin Cases 2015; 3(3): 275-84. [http://dx.doi.org/10.12998/wjcc.v3.i3.275] [PMID: 25789300]

[84] Loukas S, Varoucha D, Zioudrou C, Streaty RA, Klee WA. Opioid activities and structures of $\alpha$-casein-derived exorphins. Biochemistry 1983; 22(19): 4567-73.

[http://dx.doi.org/10.1021/bi00288a034] [PMID: 6313043]

[85] Trivedi MS, Hodgson NW, Walker SJ, Trooskens G, Nair V, Deth RC. Epigenetic effects of casein-derived opioid peptides in SH-SY5Y human neuroblastoma cells. Nutr Metab (Lond) 2015; 12: 54. [http://dx.doi.org/10.1186/s12986-015-0050-1] [PMID: 26664459]
[86] Van Campen DR. Copper interference with the intestinal absorption of zinc-65 by rats. J Nutr 1969; 97(1): 104-8.

[http://dx.doi.org/10.1093/jn/97.1.104] [PMID: 5763434]

[87] Ostlund RE Jr. Phytosterols in human nutrition. Annu Rev Nutr 2002; 22: $533-49$.

[http://dx.doi.org/10.1146/annurev.nutr.22.020702.075220] [PMID: 12055357]

[88] Cohn JS, Kamili A, Wat E, Chung RW, Tandy S. Dietary phospholipids and intestinal cholesterol absorption. Nutrients 2010; 2(2): 116-27.

[http://dx.doi.org/10.3390/nu2020116] [PMID: 22254012]

[89] Genser D. Food and drug interaction: Consequences for the nutrition/health status. Ann Nutr Metab 2008; 52(Suppl. 1): 29-32. [http://dx.doi.org/10.1159/000115345] [PMID: 18382075]

[90] Jin MJ, Han HK. Effect of piperine, a major component of black pepper, on the intestinal absorption of fexofenadine and its implication on food-drug interaction. J Food Sci 2010; 75(3): H93-6. [http://dx.doi.org/10.1111/j.1750-3841.2010.01542.x] [PMID: 20492299]

[91] Foster BC, Vandenhoek S, Hana J, et al. In vitro inhibition of human cytochrome P450-mediated metabolism of marker substrates by natural products. Phytomedicine 2003; 10(4): 334-42.

[http://dx.doi.org/10.1078/094471103322004839] [PMID: 12809364]

[92] Vaquero MP, Sánchez Muniz FJ, Jiménez Redondo S, Prats Oliván P, Higueras FJ, Bastida S. Major diet-drug interactions affecting the kinetic characteristics and hypolipidaemic properties of statins. Nutr Hosp 2010; 25(2): 193-206. [PMID: 20449528]

[93] 2017.https://patienteducation.osumc.edu/Documents/diet-ant.pdf

[94] Kao TH, Huang SC, Inbaraj BS, Chen BH. Determination of flavonoids and saponins in Gynostemma pentaphyllum (Thunb.) Makino by liquid chromatography-mass spectrometry. Anal Chim Acta 2008; 626(2): 200-11.

[http://dx.doi.org/10.1016/j.aca.2008.07.049] [PMID: 18790122]

[95] Lü L, Liu SW, Jiang SB, Wu SG. Tannin inhibits HIV-1 entry by targeting gp41. Acta Pharmacol Sin 2004; 25(2): 213-8. [PMID: 14769212]

[96] Akiyama H, Fujii K, Yamasaki O, Oono T, Iwatsuki K. Antibacterial action of several tannins against Staphylococcus aureus. J Antimicrob Chemother 2001; 48(4): 487-91.

[http://dx.doi.org/10.1093/jac/48.4.487] [PMID: 11581226]

[97] Kolodziej H, Kiderlen AF. Antileishmanial activity and immune modulatory effects of tannins and related compounds on Leishmania parasitised RAW 264.7 cells. Phytochemistry 2005; 66(17): 2056-71. [http://dx.doi.org/10.1016/j.phytochem.2005.01.011] [PMID: 16153409]

[98] Bains K, Uppal V, Kaur H. Optimization of germination time and heat treatments for enhanced availability of minerals from leguminous sprouts. J Food Sci Technol 2014; 51(5): 1016-20.

[http://dx.doi.org/10.1007/s13197-011-0582-y] [PMID: 24803714]

[99] Gupta V, Nagar R. Minerals and antinutrients profile of rabadi after different traditional preparation methods. J Food Sci Technol 2014; 51(8): 1617-21

[http://dx.doi.org/10.1007/s13197-012-0667-2] [PMID: 25114357]

[100] Devi R, Chaudhary C, Jain V, et al. Effect of soaking on antinutritional factors in the sun-dried seeds of hybrid pigeon pea to enhance their nutrients bioavailability. JPP 2018; 7(2): 675-80.

[101] Agume AS, Njintang NY, Mbofung CM. Effect of soaking and roasting on the physicochemical and pasting properties of soybean flour. Foods 2017; 6(2): 12 .

[http://dx.doi.org/10.3390/foods6020012] [PMID: 28231091]

[102] Shi L, Mu K, Arntfield SD, Nickerson MT. Changes in levels of enzyme inhibitors during soaking and cooking for pulses available in Canada. J Food Sci Technol 2017; 54(4): 1014-22.

[http://dx.doi.org/10.1007/s13197-017-2519-6] [PMID: 28303052]

[103] Binita R, Khetarpaul N. Probiotic fermentation: Effect on antinutrients and digestibility of starch and protein of indigenously developed food mixture. Nutr Health 1997; 11(3): 139-47. [http://dx.doi.org/10.1177/026010609701100301] [PMID: 9131698]

[104] Babalola RO, Giwa OE. Effect of fermentation on nutritional and antinutritional properties of fermenting Soybeans and the antagonistic effect of the fermenting organism on selected pathogens. Int Res J Microbiol 2012; 3(10): 333-8.

[105] Ojokoh AO, Daramola MK, Oluoti OJ. Effect of fermentation on nutrient and anti-nutrient composition of breadfruit (Treculia africana) and cowpea (Vigna unguiculata) blend flours. Afr J Agric Res 2013; 8(27): 3566-70. 
[http://dx.doi.org/10.5897/AJAR12.1944]

[106] Valdez-González FJ, Gutiérrez-Dorado R, García-Ulloa M, CuevasRodríguez BL, Rodríguez-González H. Effect of fermented, hardened, and dehulled of chickpea (Cicer arietinum) meals in digestibility and antinutrients in diets for tilapia (Oreochromis niloticus). Span J Agric Res 2018; 16(1)

[http://dx.doi.org/10.5424/sjar/2018161-11830]

[107] Adeyemo SM, Onilude AA, Olugbogi DO. Reduction of Antinutritional factors of sorghum by lactic acid bacteria isolated from Abacha - an African fermented staple. Front Sci 2016; 6(1): 25-30.

[108] Vidal-Valverde C, Frias J, Sierra I, et al. New functional legume food by germination: Effect on the nutritive value of beans, lentils and peas. Eur Food Res Technol 2002; 215: 472-6.

[http://dx.doi.org/10.1007/s00217-002-0602-2]

[109] Dikshit M, Ghadle M. Effect of sprouting on nutrients, antinutrients and in vitro digestibility of the MACS-13 soybean variety. Plant Foods Hum Nutr 2003; 58(3): 1-11.

[http://dx.doi.org/10.1023/B:QUAL.0000040357.70606.4c]

[110] Kanensi OJ, Ochola S, Gikonyo NK, Makokha A. Optimization of the period of steeping and germination for amaranth grain. J Agric Food Tech 2011; 1(6): 101-5.

[111] Kajla PS, Sharma A, Sood DR. Effect of germination on proximate principles, minerals and antinutrients of flaxseeds. Asian J Dairy Food Res 2017; 36(1): 52-7.

[http://dx.doi.org/10.18805/ajdfr.v36i01.7459]

[112] Chauhan ES. Effects of processing (germination and popping) on the nutritional and anti-nutritional properties of finger millet (Eleusine Coracana). Curr Res Nutr Food Sci 2018; 6(2)

[113] Fernando R, Pinto P, Pathmeswaran A. Goitrogenic food and prevalence of goitre in Sri Lanka. J Food Sci 2012; 41: 1076-81.

[114] Udousoro II, Akpan EB. Anthropometric measurements, changes in anti-nutrients contents of edible vegetables under varied temperature and heating time. Curr Res Nutr Food Sci 2014; 2(3) [http://dx.doi.org/10.12944/CRNFSJ.2.3.06]

[115] Mwanri A, Kogi-Makau W, Laswai H. Nutrients and antinutrients composition of raw, cooked and sun-dried sweet potato leaves. Afr J Food Agric Nutr Dev 2011; 11(5): 5142-56.

[116] Adeleke OR, Adiamo OQ, Fawale OS, et al. Effect of processing methods on antinutrients and oligosaccharides contents and protein digestibility of the flours of two newly developed bambara groundnut cultivars. Int Food Res J 2017; 5(9): 1006-14.

[117] Al-Kaisey MT, Alwan AKH, Mohammad MH, Saeed AH. Effect of gamma irradiation on antinutritional factors in broad bean. Radiat Phys Chem 2003; 67(3): 493-6.

[http://dx.doi.org/10.1016/S0969-806X(03)00091-4]

[118] Hassan AB, Osman GM, Rushdi MA, et al. Effect of gamma irradiation on the nutritional quality of maize cultivars (Zea mays) and sorghum (Sorghum bicolor) grains. Pak J Nutr 2009; 8: 167-.

[http://dx.doi.org/10.3923/pjn.2009.167.171]

[119] El Niely HFG. Effect of radiation processing on antinutrients, in vitro protein digestibility and protein efficiency ratio bioassay of legume seeds. Radiat Phys Chem 2007; 76: 1050-7.

[http://dx.doi.org/10.1016/j.radphyschem.2006.10.006]

[120] Fombang EN, Taylor JRN, Mbofung CMF, et al. Use of $\gamma$-irradiation to alleviate the poor protein digestibility of sorghum porridge. Food Chem 2005; 91: 695-03.

[http://dx.doi.org/10.1016/j.foodchem.2004.06.042]

[121] Osman AM, Hassan AB, Osman GA, et al. Effects of gamma irradiation and/or cooking on nutritional quality of faba bean (Vicia faba L.) cultivars seeds. J Food Sci Technol 2014; 51(8): 1554-60. [http://dx.doi.org/10.1007/s13197-012-0662-7] [PMID: 25114347]

[122] Mahmoud NS, Awad SH, Madani RM, Osman FA, Elmamoun K, Hassan AB. Effect of $\gamma$ radiation processing on fungal growth and quality characteristcs of millet grains. Food Sci Nutr 2015; 4(3): 342-7.

[http://dx.doi.org/10.1002/fsn3.295] [PMID: 27247763]

[123] Pedrosa M. Recent advances of research in antinutritional factors in legume seeds and oilseeds. Wageningen Academic Pub. In: 2004; p. 263.

[124] Shukla VK, Doyon Y, Miller JC, et al. Precise genome modification in the crop species Zea mays using zinc-finger nucleases. Nature 2009; 459(7245): 437-41.

[http://dx.doi.org/10.1038/nature07992] [PMID: 19404259]

[125] Kim H, Kim S-T, Kim S-G, et al. Targeted genome editing for crop improvement. Plant Breed Biotechnol 2015; 3(4): 283-90. [http://dx.doi.org/10.9787/PBB.2015.3.4.283]

\section{(C) 2019 Popova and Mihaylova.}

This is an open access article distributed under the terms of the Creative Commons Attribution 4.0 International Public License (CC-BY 4.0), a copy of which is available at: (https://creativecommons.org/licenses/by/4.0/legalcode). This license permits unrestricted use, distribution, and reproduction in any medium, provided the original author and source are credited. 